\title{
FICÇÃO CIENTÍFICA BRASILEIRA NO REGIME DITATORIAL: REAÇÕES DO HOMEM "MÉDIO"
}

\section{BRAZILIAN SCIENCE FICTION IN THE DICTATORIAL REGIME: REACTIONS OF THE "AVERAGE" MAN}

Vítor Castelões Gama'

Ramiro Giroldo ${ }^{2}$

\begin{abstract}
RESUMO: Este artigo visa discutir sobre a Ficçăo Científica Brasileira. Analisaremos quatro obras do período da ditadura (1964-1985) buscando uma síntese especulativa enquanto, ao mesmo tempo, contrapomos a ideia de que a FC é um gênero literário apolítico. As obras escolhidas tratam, de maneira explícita ou implícita, da violência da ditadura e suas consequências. Porém, enquanto muitas obras do período trabalharam como tema a identidade nacional e política do brasileiro, as obras analisadas aqui priorizaram as minúcias e os atos "mundanos". Por conseguinte, também partimos de um ponto de vista limitado ao homem "médio" frente aos poderes de violência estatais. Indo mais além, nos inserimos em um exercício especulativo das possíveis reaçôes deste homem a um contexto de totalitarismo.
\end{abstract}

Palavras-chave: Ficçăo científica brasileira; ditadura; André Carneiro; Jerônymo Monteiro.

ABSTRACT: This article intends to discuss Brazilian Science Fiction. We will analyze four works from the dictatorship period (1964-1985) seeking a speculative synthesis, while at the same time counteracting the idea that SF is an apolitical literary genre. The chosen works explicitly or implicitly deal with the dictatorship violence and its consequences. However, while many pieces of literature of the period have dealt with the Brazilian national and political identity as theme, as well as the basis of a "social revolution" or great critical allegories, the works analyzed here prioritized the the violence of and "worldly" ordinary acts. Therefore, we also start from a point of view limited to the "average" man's perspective of state violent powers. Going further, we enter into a speculative exercise about man's possible reactions to a context of totalitarianism.

Keywords: Brazilian science fiction; dictatorship; André Carneiro; Jerônymo Monteiro.

1 Doutorando na Universidade de Brasília, Mestre em Literatura e Práticas Sociais na UnB. Email: vitorcasteloesgama@hotmail.com

2 Professor Adjunto da Universidade Federal de Mato Grosso do Sul e pesquisador financiado pelo CNPq. Mestre em Estudos de Linguagens pela mesma instituiçáo e Doutor em Literatura pela USP. Email: r_giroldo@yahoo.com.br 


\title{
INTRODUÇÃO
}

A ditadura de 1964 ainda é um fantasma que arrepia os brasileiros, prova disto sâo os estudos históricos sobre a luta dos oprimidos contra o esquecimento e o extermínio. Eram tempos nos quais um gesto de proteçâo e cumplicidade poderia significar a morte. Neste contexto, o que a literatura pode fazer para mudar essa realidade? Nem todos podem partir para a rebeliăo armada, mas, existir, quando lhe querem morto, também tem seu aspecto revolucionário. A literatura, mesmo fora das trincheiras, ao criticar a sociedade ou registrar as memórias dos silenciados, pode oferecer um gesto de cumplicidade. Argumentamos que a ficçăo científica ${ }^{3}$ exerceu e ainda exerce este papel em várias narrativas contemporâneas.

Neste artigo, examinaremos a FC por esta ótica política. Cabe ressaltar que o acesso a referências estrangeiras permitiu que a FC florescesse durante o período ditatorial (1964-1985), mas, sua popularidade também é devida ao fato de ter sido largamente utilizada para escapar da censura. Por esse motivo, a FC foi aceita pelos escritores de outros gêneros. Entretanto, o mesmo năo aconteceu em relaçăo à crítica da época. Por exemplo, Otto Maria Carpeaux acusa a FC de alienaçăo:

\begin{abstract}
'Literariamente, a consequência é a baixa realidade: literatura de cordel.' [...] 'Essa literatura de cordel fornece ao leitor comum todas as trivialidades, horrores, sentimentalismos etc. que a literatura moderna exclui cuidadosamente dos seus enredos (ou da sua falta de enredo). A science-fiction faz questăo de náo tocar nunca em problemas psicológicos ou questóes sociais. Ao embarcar para o espaço, perdeu o contato năo só com a Terra, mas também com a realidade. Evasăo? Mas essa evasăo tem objetivo bem definido: cancelar um processo histórico' (BRAS, 2019, p. 4).
\end{abstract}

A subsistência desta postura negativa em relaçăo ao gênero é comprovada pelo fato de Luiz Bras, sessenta anos depois, ter de retorquir as palavras de Carpeaux para defender a FC. Há uma predisposiçâo a considerar apenas os ataques concretos ao Regime Militar, realizados por meio da literatura, como exemplo de obras engajadas. A maior dificuldade dos críticos avessos ao gênero é reconhecer a sociedade retratada pela FC, pois, como aponta Naiara Sales Araújo (2014, p. 61), as críticas sociais encontram-se camufladas por estratégias genéricas e pela utilizaçăo da linguagem figurada. Acrescentamos que durante o período ditatorial algumas obras disfarçavam o posicionamento político ao eleger como tema as minúcias cotidianas, por exemplo, a rotina e a vida familiar. Para o leitor acostumado com o gênero, o "desvio" da vida cotidiana aponta rasgos e dissonâncias com a realidade subjacente que permitem, ao leitor, recompor e comparar o mundo criado pela obra.

A análise tem como base quatro obras produzidas no Estado de exceçâo: 1) “O copo de cristal", de Jerônymo Monteiro; 2) "A sociedade secreta", de Domingos Carvalho da Silva; 3) A invasâo, de José Antonio Severo; 4) “O gabinete blindado”, de André Carneiro. A primeira acompanha o protagonista Miguel após a redescoberta de uma taça de cristal, vinculada ao seu passado. O objeto em questăo reflete imagens que revelam um segredo sobre o futuro da humanidade. A segunda obra mantém o tom memorialístico

3 Doravante FC ou FCB (ficçăo científica brasileira) 
ao assistir um grupo de idosos retornando às vivências do passado para contrapor o presente "utópico" ao passado pobre, mas, livre. A terceira obra, ao contrário das outras, que sâo contos, é um romance sobre os preparativos e a invasâo do Brasil em Angola. A finalidade é tirar o controle do país Africano das máos dos comunistas cubanos, objetivando relaçôes econômicas privilegiadas. Por fim, o último conto observa e reflete sobre a vida interrompida de pessoas comuns que se tornaram guerrilheiras. $O$ grupo composto por "N", “P", “Jorge", "Sally", entre outros, reúnem-se para atacar um gabinete blindado, um objetivo que se prova elusivo.

As obras escolhidas além de demonstrar a violência da ditadura, focalizam as minúcias e os atos "mundanos" em detrimento de grandes aventuras interplanetárias. Em todas elas, a rotina pessoal e familiar é desestabilizada por elementos externos; espera-se, entăo, que o leitor receie que a desestabilizaçăo também venha a ocorrer no próprio seio familiar. Mesmo nas duas últimas obras, cujo título e enredo sugerem mais açăo, o foco narrativo demonstra que o tema é o mesmo: a interrupçăo da vida comum pela violência da ditadura.

Na análise, buscamos compreender a visáo destes personagens, que chamamos de homens "médios", ao serem confrontados pela violência estatal. ${ }^{4}$ Nos inserimos em um exercício especulativo das possíveis reaçôes destes homens a um contexto de totalitarismo: o que esses personagens fariam quando confrontados pela perda de liberdade social e política? Em suma, buscamos compreender como as obras analisadas trabalham e ressignificam, por meio de seus personagens, a violência (física e psicológica) desse período histórico. ${ }^{5}$

\section{A CAVERNA DE "O COPO DE CRISTAL"}

"O Copo de Cristal" foi publicado em 1969, mas escrito um mês após o golpe militar que derrubou o governo do presidente Joâo Goulart. A prontidăo de Jerônymo, como ressalta Roberto de Sousa Causo (2007, p. 92), "contesta o senso comum de que os autores da década de 1960 se abstiveram de criticar o golpe de estado", e o forte teor autobiográfico da narrativa náo passa despercebido pelo leitor. Como já mencionado, a redescoberta do objeto é o gatilho que movimenta o enredo e que leva o protagonista a refletir sobre a prisăo recente:

[N]ovamente a perua, a estrada e o xadrez do DOPS. Assim de homens. Comunistas. Piso de cimento, nem um banco, nem um colchăo. Centenas de homens estendidos pelo chăo e alguns caminhando cuidadosamente entre os corpos, para năo os pisar,

4 Entendemos o homem "médio" como aquele derivado do direito penal, ou seja, uma abstraçăo jurídica sem autoria determinada (MARTIN, 2003). Este é o homem consciencioso e prudente que serve de balança moral para os outros. Porém, esta mesma figura é hoje relacionada ao homem de pouca coragem e, contraditoriamente, de moral duvidosa. Apesar de ser uma abstraçáo, a visâo do homem "médio" é compreensível: o homem cujo maior temor, ao contrário de Heitor de Tróia, năo é morrer desonrado, mas, esquecer-se de pagar em dia o carnê.

5 Apesar das continências históricas, interpretamos as obras com vistas a situaçôes recentes para ser possível aprender um pouco deste passado que se torna presente. Portanto, este artigo diz mais sobre a atualidade do que do passado em si - o que também é uma constante na FC que aborda as potencialidades do futuro. 
a maioria seminus, porque o calor era sufocante na enorme sala sem ventilaçăo. A privada, ao canto, aberta a todos os olhos. As horas infindáveis, agoniadas pela falta de ar, pelo cheiro, pela revolta. Depois, a triagem. [...] A alma pesada, o corpo desfeito, o cérebro desordenado pela frustraçăo, a condiçăo humana esmagada pela humilhaçăo". (MONTEIRO, 1969, p. 67-68).

A estrutura narrativa escolhida reflete o trauma e a violência sofrida durante a estadia no Departamento de Ordem Política e Social (DOPS), órgáo de repressâo. Os reflexos começam na escolha do narrador de tipo onisciente que, ao contrário do esperado, năo sabe de tudo e expóe os acontecimentos de forma fragmentária. O objetivo é confundir a figura do narrador-espectador com a figura de um narrador-participante, neste caso Miguel. Assim, cria-se um contexto de significaçăo no qual o espectador, também pode ser vítima. Em seguida, o discurso indireto livre é utilizado para expressar as dúvidas do personagem subjugado pelas violências sofridas, como no momento em que relembra o copo: "pouco a pouco a memória foi juntando os fiapos soltos e com eles teceu a cena sepultada e esquecida havia meio século" (MONTEIRO, 1969, p. 68). Destacamos a associaçăo do objeto à agressăo em duas instâncias: a violência política e a familiar. Miguel lembrou-se, além das surras frequentes quando criança, de que o copo na escuridăo projetava um teatro de sombras azulado, em que os limites e contornos da "fantasmagoria" năo eram claros outrora e tampouco o sâo agora. Mesmo sem entender as imagens, o espetáculo era uma fuga prazerosa que acalmava as memórias do cárcere:

[X]adrez, os corpos pelo chăo, a privada aberta a todos os olhares. Como a morte, a fuga dos pássaros. Uma escura e feia mancha se estendeu sobre a casa e a paisagem, extravasando do seu espírito acabrunhado, mancha que se alastrava e cobria a pequena cidade, o litoral, o Estado, o país. Como a laje de um túmulo. Dentro do túmulo náo se pode falar, nem ouvir, nem pensar. Dentro do túmulo jaz o corpo morto. A privada ao canto. Quem se acocorasse sobre ela, à vista de centenas de outros homens, ficava inibido, esmagado. Era assim. A privada, o mundo todo olhando. (MONTEIRO, 1969, p. 73).

É significativo que o país e o personagem năo possam falar, ouvir, pensar e aduzimos que também năo possam ver. Năo há voz, nem som, a visăo turva, a humanidade desgarrada do corpo e a mente definha, um reflexo do cenário em que o autor se emaranhava, quase que moribundo, metafórica e literalmente. Considerando que a privaçăo dos sentidos e a conexăo com o mundo é um dos principais métodos de tortura fica implícito que Miguel também fora torturado. A tortura, para Idelber Avelar, invariavelmente tem o objetivo de

[G]erar um efeito de autodesprezo, vergonha, traiçáo e derrota. A produçăo forçada de enunciados durante o ato de tortura pode levar a um trauma que afunda o sujeito no completo silêncio. $O$ torturador obriga a falar para que depois você silencie por completo, para que você nunca mais queira falar. A tortura produz discurso para produzir silêncio. (AVELAR, 2011, p. 65)

A produçâo do silêncio explica o laconismo do personagem que para resistir ao sofrimento utiliza as imagens refletidas pelo objeto como acalanto: "o som de um apito 
chamou-o à realidade. Em seguida, o ruído violento do trem, passando ao lado da casa, estraçalhou o silêncio e a quietude. [...] Passara toda a noite a olhar aquela irrealidade que ressurgia do fundo do seu passado." (MONTEIRO, 1969, p. 78). O personagem crê que as imagens refletidas săo falsas e que seu hipnotismo o salvaria, por alguns momentos, das dolorosas rememoraçóes. Entretanto, uma reviravolta é prefigurada pelo estranhamento cognitivo da FC, ou seja, o ato de tornar a realidade factual visível de outra forma. ${ }^{6} \mathrm{O}$ objeto exerce esta funçăo de estranhamento ao mostrar uma realidade para Miguel cuja força é como a de um trem desgovernado, realidade esta a qual o protagonista mantivera os olhos fechados. A verdade sobre o copo é revelada com o auxílio de Car, a esposa de Miguel, pois ao contrário do marido, ela conseguia distinguir formas precisas. As figuras acalentadoras eram homens que "se destroem como animais selvagens! Retalham-se com as espadas, perfuram-se com as lanças. Fazem-se em pedaços. Jorra sangue em abundância. Os que correm pisam no que se estăo estorcendo no chấo, feridos. Devem estar gritando" (MONTEIRO, 1969, p. 82). A personagem recusou-se a continuar vendo a selvageria, pois năo se rendia ao apelo da violência. Porém, após uma pausa continuaram a desvendar as imagens e entăo observam uma tabuleta escrita "Drink Coca-cola?". Seriam as imagens vindas nâo do passado, mas do futuro? É nesse ponto que Miguel consegue recompor a sua visăo do mundo e sair de uma posiçấo de completo espectador para a de um possível agente: “Creio, mesmo, que o mais provável futuro para o homem seja esse, se ele continuar pelo caminho que vai. Os homens nunca se entenderam. Há sempre uma ameaça de guerra e cada vez de guerra pior." (MONTEIRO, 1969, p.87).

Por fim, ao raiar do dia, os personagens deixam o teatro de sombras e, em um incêndio, o copo é destruído. Interpretamos este final como a recusa dos personagens em continuar apenas observando a violência ao seu redor, sem agir. Náo é fácil definir a motivaçăo da passividade de Miguel, que como muitos homens, ignorava a violência e perante a dor dos outros, se emudecia. A violência da sociedade tornou Miguel apático, percebia violência como natural, pois foi criado desta forma, como se náo houvesse alternativas a ela.É com esse objetivo que Car é contraposta na diegese, uma vez que ela é a única personagem que năo demonstrou ter medo de lutar por seus direitos e buscar a justiça. Ela foi a única que viu o espetáculo do copo pelo o que ele era de verdade: selvageria. Portanto, em estrutura e enredo, $\mathrm{O}$ copo de cristal demonstra que o silêncio nâo é suficiente, é necessário agir.

\section{A SOCIEDADE SECRETA - NOSTALGIA E RESIGNAÇÃO}

Os personagens do conto de Jerônymo Monteiro tomaram consciência dos erros da sociedade e a necessidade de agir em vez de permanecer passivo. Já o conto de Domingos Carvalho da Silva, publicado em 1966, demonstra que a nostalgia pode convencer o homem "médio" a năo se rebelar perante as desigualdades. Perceber as injustiças nâo determina que o indivíduo vá agir para mudar esta realidade e os motivos sâo diversos. A narrativa começa com a descriçáo

6 Darko Suvin(2016) postula que o estranhamento cognitivo da FC é realizado por meio do "novum" que introduz algo de desconhecido no mundo empírico do autor e do leitor, criando assim uma forma de estranhamento determinante para a lógica narrativa. 
de uma utopia cujo preço é o controle de todos os aspectos sociais, no conto, até a arte fora padronizada: "a obra de arte" - disseram-lhe - "foi sempre coletiva. Shakespeare jamais existiu: foi um mito, como Homero. Cervantes foi apenas um contador de histórias aprendidas com o povo. Mozart é uma lenda!" (SILVA, 1966, p. 40), indigna-se o narrador, um dos dez ancióes da sociedade secreta. 0 narrador lamenta:

Estávamos proibidos de recordar o passado, de pensar na morte ou em doenças, de ser permeáveis a qualquer motivo de melancolia, semente de neuroses. A saudade de outrora, além de ser ofensa à civilizaçăo total da nova época, era um elemento psicológico pernicioso e, sob certos aspectos, subversivo: saudosos do nosso mundo, estaríamos conspirando contra o mundo novo e poderíamos disseminar o vírus da dúvida e do descontentamento (SILVA, 1966, p. 42-43).

A nostalgia pode ser fruto do descontentamento com o presente, afinal, é normal querer restaurar o que se acreditava que havia de bom no passado. Entretanto, os personagens do conto caíram na mesma contradiçâo do regime que criticavam, foram revisionistas. Nâo diziam que Shakespeare ou Mozart nâo existiam, mas, sentiam falta até da fome, das doenças e da miséria. Porém, aponta-se que a perfeiçâo desta sociedade é ilusória, pois ainda há gula, corrupçâo e estratificaçấo social. É por meio da corrupçâo que os dez anciōes conseguem acessar o subsolo para as reunióes do grupo. No subsolo, para a surpresa dos participantes, sâo encontrados ratos:

náo havia uma teia de aranha nem uma barata, mesmo porque baratas e aranhas tinham sido extintas alguns decênios antes. Foi por isso com grande surpresa que a nossa companheira M.F.18-IV etc., Maria da Glória na intimidade, descobriu e identificou, em nossa quinta sessăo, a presença de enorme ratazana, instalada em confortável toca junto ao canal. Foi uma alegria! Um rato! Se ainda havia ratos, poderia haver também, em lugares secretos, morcegos e cupins! (SILVA, 1966, p. 44)

Todas as "pestes" haviam sido "higienizadas" por meio de um sistema de denúncias, mas a presença destes animais e dos anciōes indicava que a reformulaçăo do sistema é possível. Em termos socioecológicos a própria existência dos ratos é a promessa de uma sociedade saudável, uma vez que o principal papel dos ratos, baratas, e moscas é decompor a podridâo. Como racionalizam os anciōes:

Por isso festejamos aquele rato em liberdade, que percorria as galerias subterrâneas, que escolhia sua fêmea, que roía o que houvesse para roer, que poderia atordoar os canais com seus guinchos e que era, como nós, um sobrevivente do capitalismo e da democracia liberal, um ser escapo do mecanismo do interesse coletivo, uma coisa insólita como um dinossauro em férias em Hyde Park (SILVA, 1966, p. 44).

Nesta passagem, a "democracia" é comparada ao extermínio, uma associaçăo de conceitos incomum naquele período histórico, mas, que hoje parece corriqueira. Também é contraditório o dinossauro em Hyde Park, parque que foi palco de inúmeros protestos e que ficou famoso pela Grande Exibiçăo de 1851 de teor futurista, assim como por ter se tornado ponto de encontro dos movimentos que defendiam a liberdade 
de expressăo na Europa. O anacronismo do dinossauro, entăo, representa na fala dos personagens o regime totalitário que nega os direitos básicos, mas que se veste como o ápice do desenvolvimento social e tecnológico.

A obra parece corroborar os anseios desenvolvimentistas ao verbalizar os desejos higienistas da época, mas, também crítica estes mesmos anseios sutilmente. No desfecho do conto, os ratos acabam mortos e os "conspiradores" presos, a vida e o destino deles ficaram intimamente conectados à dos roedores, "os gatos caçavam-nos. As ratoeiras caçavam-nos. E nós náo suspeitávamos de que, ligado ao seu destino, estava o nosso. 0 mundo que lhes ia destruir a buraqueira onde habitavam, que lhes ia proibir o trânsito livre, também nos furtaria esse mesmo gosto" (SILVA, 1966, p. 46). Os anciōes foram julgados subversivos por serem, como os ratos, "inimigos da civilizaçăo e da ordem" e condenados a voltar para 1960, onde o narrador viu um idoso magro à frente de um carro de boi. O mais espantoso era que apesar da fome, "o velho cantava uma cançâo sentimental e gaiata. E náo aparecia ninguém para prendê-lo, nenhum computador denunciou aquela alegria que, na miséria, feria todos os regulamentos!" (SILVA, 1966, p. 48).

O fim do conto é inesperado uma vez que a pena sofrida pelos idosos era, na verdade, o que mais desejavam. Este final teve o objetivo de questionar a tendência nostálgica dos homens "médios" como também questionar o conceito de progresso: a nostalgia que buscavam é realmente progresso? Da mesma forma, uma utopia na qual é preferível morrer de fome a viver sem liberdade pode ser considerada boa? "A sociedade secreta", ao inserir um impasse entre o passado e futuro, demonstra a existência de entraves à açăo do homem "médio". Espera-se que ele decida seguir o caminho em direçâo a algo ruim ou voltar para algo que talvez seja pior. Enquanto isso se fica na encruzilhada.

\section{A INVASÃO E A CRISE SACRIFICIAL DE GIRARD}

As duas obras anteriores tencionavam o homem "médio" à açăo. Enquanto "O copo de cristal" sugeria que sair da inércia era necessário, "A sociedade secreta" justificava os motivos da paralisia. A terceira obra é clara ao sugerir um rumo ao homem "médio". A invasâo, romance escrito em 1979, portanto, sugere a este homem que adira ao regime, que corrobore os posicionamentos da sociedade vigente.

A obra especula um futuro alternativo, subgênero da ficçâo cientifica, ao dramatizar acontecimentos da década de 1970 em Angola. Este país, após uma guerra de independência, estaria perdendo o controle político para os Cubanos. Na trama, o próprio presidente angolano sugere ao Brasil que este invada o país africano e expulse os inimigos em troca de riquezas estratégicas. Para o crítico Marcello Simăo Branco, esta obra é

[T]alvez, um dos poucos trabalhos com uma postura mais favorável aos militares. Procura ilustrar parte da mentalidade dos dirigentes da época, com delírios de transformar o Brasil numa potência econômica e, sobretudo, militar, com liderança entre os países do Terceiro Mundo (BRANCO, 2010, p. 29).

A invasâo difere-se das outras obras nâo apenas pelo alinhamento político, mas também pelo gênero literário: o romance. 0 ponto de vista narrativo demonstra-se 
completamente objetivo e onisciente, năo há dúvidas ou dilemas nos personagens que, em certos momentos, parecem intercambiáveis. Ademais, o heroísmo em batalha náo parece um atributo do homem "médio"; entâo, haveria algum personagem deste tipo em todo o romance?7 Propomos que todos os personagens da narrativa săo "médios", uma perspectiva teórica pode iluminar melhor essa questăo e outras contradiçóes da obra: o desejo mimético e a crise sacrificial de René Girard. ${ }^{8}$ Cabe ressaltar que, em 1979, o Brasil começava a ser visto como um país emergente; entretanto, ficou claro também na mesma época que o desenvolvimento tăo propagandeado năo chegaria a todos. Para o personagem da diegese importa saber quem é o culpado, quem nos atrapalhou no caminho ao "primeiro mundo"? Em um passe de mágica ,ou em uma jogada de marketing, passa-se a ressentir o "culpado" por nossas falhas e por este crime deve ser punido com a morte.

O sacrifício era já um assassinato, mas um assassinato coletivo que permitia, como bem percebeu R. Girard, administrar a violência interna do grupo. Desde que esse mecanismo năo existe mais (e năo é o caso de lamentar sua falta), os homens adotaram outro: permitir, em momentos privilegiados, que a violência do grupo se exprima no exterior em guerras ou em massacres; expulsar os impuros do templo exterminando todos os que poderiam representar o antigo mundo condenado ao extermínio ou à redençáo (os judeus, os bolchevistas ou, como para o Khmer Vermelho, todos os velhos, os pais, os que haviam conhecido o antigo mundo e puderam apreciá-lo, especialmente os intelectuais que tinham a petulância de querer pensar). Nâo é mais possível, portanto, selecionar. É preciso eliminar todos os que năo querem ou năo săo capazes de querer a nova ordem ("O Reich que vai durar 1.000 anos!"). Ao transformá-los em estrangeiros, em animais, em bichos nocivos, pode-se mobilizar o povo contra eles ou, pelo menos, obter sua adesăo muda e sua passividade. (ENRIQUEZ, 2015, p. 183-184)

A crise sacrificial, nos termos de Girard, é exposta nas primeiras páginas do romance quando a velha guarda de um jornal denuncia os jovens jornalistas taxando-os de comunistas aos militares. O motivo? Ressentimento pela mudança. Na sociedade da obra, os comunistas seriam os verdadeiros culpados pela falta de rumo do país, mas de súbito transfere-se a parcela de "culpa" dos comunistas brasileiros aos Cubanos, estes que exerceráo o papel de sacrificados. Transfere-se a culpa dos problemas sociais a uma espécie de avatar que corporificará e expiará os pecados, como o mito bíblico de Azazel. Apenas com o sacrifício dos outros, que o Brasil conseguiria uma melhor posiçăo geopolítica. O desejo năo é a aniquilaçăo dos Cubanos (sujeito 2), mas, a posiçăo estratégica (objeto) que possuem em Angola. Mais a fundo, o desejo é ter a potência econômica (objeto) de Angola, que a estabeleceria como rival no panorama mundial. “O fatalismo geográfico aproximaria Brasil e Angola ou os tornaria adversários, quando

7 Não queremos dizer que os homens comuns não podem ser heróis, em nosso ponto de vista interpretativo isto seria absurdo.Entendemos o herói como aquela figura central, dotada de valores posítivos "em termos axiológicos, sociais ou morais" (REIS, 2018, p. 193). Os heróis são aqueles que vencem o medo eque são heróis apesar do medo. Na obra de Severo ninguém demonstra temor.Ou não o sentem, ou simulam e, portanto, não podem ser heroicos.

8 O desejo mimético resume-se na proposição "desejo aquilo que o outro deseja", portanto, trata-se de uma relação sujeito-objeto-sujeito. A crise sacrificial é um conflito na sociedade resolvido pelo sacrifício de um inocente que será investido de todos os pecados da sociedade. A violência praticada no bode expiatório seria um tipo de violência permitida para substituir a vingança e o assassinato. Conforme mais e mais ódio é acumulado pela sociedade, mais sacrifícios são necessários. 
a África chegasse ao nível de organizaçăo que possibilitasse às suas naçōes mais ricas buscarem um lugar no mundo" (SEVERO, 1979, p. 20).

Em resumo, o Brasil na visâo dos personagens náo estava no lugar que merecia e a culpa era dos Cubanos. A uniâo contra esse inimigo criou a coesăo do povo brasileiro que deixou as diferenças políticas de lado pelo bem da guerra. Necessitavam de um líder e um dos políticos no congresso se adianta e propōe uma soluçăo "destinada a suplantar a gravidade do momento, mas de amplas repercussóes para a vida do País, enquanto o Brasil for uma Naçâo (e o será por muitos e muitos séculos para a grandeza do Mundo da vida civilizada)" (SEVERO, 1997, p. 199). Curiosamente a soluçăo é restaurar o Império Brasileiro, que, em outro plano significaria também a "restauraçăo" da grandeza do Brasil:

O Imperador pode usar algumas de suas medalhas no peito. Ficou, sem dúvida, um monarca respeitável, com seu metro e oitenta e tantos, os cabelos grisalhos, o bigode esbranquiçado, o corpo magro, mas vigoroso. E também seria um dos mais nobres do mundo, melhor que o espanhol e que os nórdicos, pois Dom Pedro III carrega os sobrenomes dos Bourbon, dos Orleans e dos Bragança (SEVERO, 1997, p. 206)

A "nobreza" de Dom Pedro é um momento de orgulho para os personagens, que partilham deste e outros símbolos para justificar sua missăo sagrada, mas, de uma forma peculiar. Ela é ao mesmo tempo causa e consequência da guerra.

De qualquer forma, o símbolo foi necessário e todos os soldados civis puderam virar heróis de guerra como, por exemplo, o personagem Amaro Silveira, que morreu em um ato de bravura. Nâo apenas os soldados civis brasileiros morreram (e năo eram velados, apenas vingados), mas também os civis năo-soldados, cujas mortes eram justificáveis se morresse algum Cubano: "Morreram muitos civis, pessoas que simplesmente fugiam pelas estradas; mas também várias unidades cubanas foram atingidas em cheio, tentando, à luz do dia, atacar o pessoal que havia tomado o aeroporto" (SEVERO, 1997, p. 110). As consequências náo importavam, o importante era tirar os cubanos. Surpreendentemente, nenhum brasileiro expressa dúvida sobre a moral do que faziam, havia apenas surpresa. Após e durante a guerra, os personagens que pareciam autônomos se tornam, entâo, idênticos.

Qual a fonte desta unanimidade misteriosa? Na crise sacrificial, os antagonistas invariavelmente acreditam estar separados por uma diferença abissal. Na realidade, todas as diferenças desaparecem pouco a pouco. Em toda parte há o mesmo desejo, o mesmo ódio, a mesma estratégia, a mesma ilusăo de diferença enorme dentro uma uniformizaçăo sempre mais completa. (GIRARD, 2005, p. 83, traduçáo nossa) ${ }^{9}$

9 No original: What is the source of this mysterious unanimity? The antagonists caught up in the sacrificial crisis invariably believe themselves separated by insurmountable differences. In reality, however, these differences gradually wear away. Everywhere we now encounter the same desire, the same antagonism, the same strategies-the same illusion of rigid differentiation within a pattern of ever-expanding uniformity. 
A indiferenciaçáo final demonstra que sequer há algum personagem tornado-se heroico, săo, deveras, todos homens "médios". Homens que sacrificam os outros em prol de algo tăo vago que é inalcançável, tanto que, por náo saber o que buscam, o romance termina sem conclusăo. A restauraçâo da grandeza, do nobre Império, que era o objetivo, năo foi suficiente. Afinal, nada mudou. Aceitaram cegamente o que lhe diziam e esperaram ansiosos pelos dividendos que nâo chegaram. Entretanto, a adesăo à violência do regime ao menos garantiu o prazer do ódio endereçado ao outro, pois esse ódio é mais confortável que o auto-desprezo, melhor que a angústia do silenciamento e melhor que a ansiedade de estar inerte.

\section{O GABINETE BLINDADO E A ESPERANÇA SOTERRADA}

As obras anteriores mostram tentativas de agir contra o que se entende de errado no mundo, de forma a tornar a sociedade mais justa. Nelas, os personagens compreenderam o caminho necessário para chegar ao objetivo pretendido: negar a violência, voltar ao passado, sacrificar o outro. Na última obra, diferentemente, năo fica claro o que os personagens precisam fazer para mudar a sociedade. A açăo é sempre interrompida pelas indecisóes dos personagens, indecisấo esta que reverbera na linguagem do conto, a qual se torna mais incerta, é possível dizer que o conto começa e termina in media res. Ademais, também há diferenças na maneira em que as obras se relacionam com a ficçăo cientifica. Na primeira, o enredo é clássico: um objeto misterioso que introduz uma novum; a segunda obra encaixa-se no subgênero utópico; a terceira no futuro alternativo.

"O gabinete blindado" utiliza o subgênero futuro alternativo e a criaçáo de mundos da FC, como visto em "O copo de cristal", mas, neste caso o espelhamento focaliza a subjetividade das pessoas comuns, como a personagem professora-pesquisadora. Em vez de criar marcadores que indicam as semelhanças e diferenças do mundo ficcional com o real, marcadores estes que geralmente săo distantes do esperado, um copo estranho, uma pistola laser, no conto de André Carneiro é o próprio ato de marcaçăo, a mente que percebe os objetos, que indica a representaçăo da sociedade brasileira da época. A obra demonstra uma recusa explícita ao regime autoritário, mas nele, transparecem dúvidas sobre o ato revolucionário. Ela também evoca as situaçóes reais da ditadura e da vida do autor, pois o autor, na primeira semana do golpe foge e adota uma nova identidade, como o mesmo admite em uma entrevista ao pesquisador Ramiro Giroldo:

\footnotetext{
“O golpe militar me jogou num abismo, repentinamente. De um dia para o outro eu me vi fugindo da polícia, arriscando a ser morto, em casa de subversivos da maior importância e maior coragem. E daí por diante. E percebi que eu năo tinha a menor importância do ponto de vista legal. Minha primeira mulher foi ter com o capităo, do qual éramos conhecidos superficiais, e falou: "O meu marido é inocente." Ele deu uma resposta maravilhosa: "Nós năo estamos interessados na inocência dele, estamos só interessados na culpabilidade." Eu achei essa resposta extraordinária. Todo mundo é condenado desse jeito. E essa ânsia de poder me defender, de lutar por uma liberdade, tornou-se uma coisa imanente dentro de mim. E, certamente, acaba vazando para minha obra" (GIROLDO, 2016, p. 148).
} 
A narrativa é contada pelo ponto de vista incerto de uma das integrantes do grupo guerrilheiro. Os tempos narrativos se misturam e novamente o discurso indireto livre aparece para desestabilizar a estrutura do conto. "Escrevo de qualquer jeito... Recordaçóes parecem fugas. Sáo mesmo...Quando começou, disfarçavam, mas ficava a face do silêncio. E o meu nada, só reflexăo." (CARNEIRO, 2010, p. 79). Como exemplo de consciência difusa, a narraçâo do dia-a-dia, da preparaçăo de um atentado é relatada em seus detalhes corriqueiros: a dificuldade de memorizar os codinomes e a estranheza dos disfarces é recorrente. Entre as reminiscências da personagem, percebe-se o leit motiv da obra: uma indecidibilidade perante aborto e concepçăo, esperança e desesperança de uma alternativa ao regime totalitarista.

A pílula mudara tudo, mulheres fascinadas, a promiscuidade liberta. Nenhuma pílula trazia regulamentos do novo paradigma. Éden mastigado sem nenhuma semente. [...] Eu tinha medo de ficar grávida. Já acontecera. Tetrahidrocanabinol. Esquecera da camisinha, ou fora a pílula ou... Tive de ficar sentada naquele hospital duvidoso, esperando nem me lembro mais o quê." (CARNEIRO, 2010, p. 80-81).

A personagem demonstra as dúvidas quanto às promessas da revoluçăo, e seu disfarce "óculos escuros, um travesseiro imitando a gravidez" simboliza a gestaçâo do futuro, ao mesmo tempo, "foi um alívio soltar a barriga de penas" (CARNEIRO, 2010, p. 83).

A revolta náo parece ter sido uma escolha fácil para a personagem, talvez, uma imposiçấo pelos planos destruídos com a ditadura. "Se conseguisse iria ao doutorado, bolsas. A bala era para mim, ela saltou; caímos juntas, ela ficou imóvel" (CARNEIRO, 2010, p. 82). Professores, pesquisadores, estudantes com suas vidas ordenadas mudadas pela bala: um momento em sala, noutros fugindo pelas ruas e se escondendo em buracos e vielas. É a esperança ou a desesperança que dá forças? Retomando o atentando que se realizara pelo subsolo, em certo momento, a personagem pondera se deve sair da escuridâo, do buraco: “Tenho fome, já comi o que levava. O bueiro final pouco significa. Só vou levantar a tampa de ferro e olhar. Minhas máos se ferem na aspereza da tampa. Preciso de uma alavanca. Temo fazer barulho... me descobrirem." (CARNEIRO, 2010, p. 84). Retornar ao mundo que náo permite a sua existência náo é uma escolha fácil e ainda năo havia chegado o seu momento, o momento do parto, e exclama

volto lentamente para o útero da terra; p me agarra, ferindo meus braços. Jorge consegue me empurrar atéa beira do vagăo inclinado. [...] Subi, atravessei um labirinto de detritos. Por uma fenda estreita alcancei a cidade enfumaçada, destruída, vazia, ao meu redor. Mancando, braços vermelhos de sangue, me arrastei pelo meio da rua. Nunca mais vi Jorge e Sally. (CARNEIRO, 2010, p. 84-85).

No fim, há apenas o sangue e o aborto. Neste contexto, a personagem deve escolher se desiste e volta à cidade ou continua na escuridão resistindo. Talvez, a personagem possa tentar se restabelecer em alguma outra cidade, ou criar a família que lhe foi negada, de qualquer forma as escolhas tornaram se muito limitadas e o sonho que tinha, teve de ser negado. Similarmente, para o homem "médio" que caminhos são possíveis frente a violência? 


\section{CONSIDERAÇÕES FINAIS}

Pensar sobre o futuro, apesar de natural, năo é uma atividade fácil. Como ressalta George Minois (2016, p. 1), predizer "é uma dimensâo fundamental de sua existência. Todos nós temos um pé no presente e outro no futuro. Viver é antecipar incessantemente, e cada uma de nossas açóes tende para um alvo situado no futuro." A história lembra-se de alguns profetas e esquece-se de inúmeros outros, crucificados pelos erros de suas prediçôes. As obras analisadas neste artigo caminham no terreno instável do futuro e tentam especular durante um momento histórico mais do que incerto, caso estejam certas, talvez o tempo diga, mas o que poderiam dizer como crítica era significativo na época e também o é hoje. Em outras palavras, a maneira pela qual as obras falam de seu tempo possui um alcance amplo, um interesse no futuro que ultrapassa ou ignora o potencial de prever empiricamente os rumos da história vindoura.

Em "O copo de cristal", os abusos sofridos pelo protagonista o levam a fechar os olhos para a violência, mas, no seu otimismo, Monteiro mostra uma escapatória, um caminho fora do ciclo vicioso da violência. Mesmo diante de um cenário odioso, a esperança utópica prevalece. "A sociedade secreta" expóe a insegurança da nostalgia que romantiza os aspectos negativos da sociedade e nos lembra de que algumas vezes somos nós que estamos atrapalhando o progresso. Essa imobilidade nostálgica pode levar à resignaçăo. A invasâo narra o uso do mecanismo de bode expiatório em favor do totalitarismo. Por meio desse mecanismo faz recair sobre os outros os próprios pecados e, ao mesmo tempo, cria uma "missăo sagrada" favorável aos anseios do regime, portanto, aderindo ao credo da ditadura e demonstrando o quáo fácil é para o homem "médio" se isentar ou aderir à violência. Por fim, "O gabinete blindado" demonstra formas diferentes de pensar a revoluçấo: a esperança, misturada com o desespero. Representada também pela contraposiçấo de gravidez e aborto e, portanto, as muitas dúvidas daquele que resiste, mas nâo sabe até onde é levado e até onde aguenta. Somos assim também?

Por meio das quatro obras analisadas, percebe-se que a FCB, no período ditatorial tinha uma preocupaçăo reflexiva sobre a situaçâo política e, portanto, sâo politizadas. Ou seja, nâo é alheia ao seu momento histórico e dialoga com ele de diferentes maneiras - tanto que se mostram férteis a uma discussăo como a travada neste texto. Săo politizadas no sentido aqui proposto, mas escapam à noçăo de "literatura engajada" cultivada por Carpeaux e outros. Esta, lembremos, seria aquela jornalística, aquela das revoluçóes bem-sucedidas, aquela nas quais os homens e mulheres náo teriam dúvidas de sua missâo. Para levar em conta as especificidades das obras aqui discutidas, portanto, faz-se necessária uma outra noçấo de engajamento ou de politizaçăo - uma noçấo que contemple o ambivalente olhar que os paradigmas constitutivos da ficçáo científica voltam para o presente e para o futuro. 


\section{REFERÊNCIAS}

AVELAR, Idelber. Figuras da violência: ensaios sobre narrativa, ética e música popular. Belo Horizonte: Editora UFMG, 2011.

BRANCO, Marcello Simăo. Afinidades Eletivas entre Ficçâo Científica e Política. In: BRANCO, Marcello Simâo (org.). Assembléia estelar: histórias de ficçâo científica política. Sâo Paulo: Devir, 2010. Pp. 9-36.

BRAS, Luiz. Brito versus Carpeaux: uma guerra infinita? In: Cândido. n 91. Pp. 04-05, 2019.Disponível em: http://www.candido.bpp.pr.gov.br/modules/noticias/article. php?storyid=240Acesso em: 01/07/2019.

CARNEIRO, André. Gabinete Blindado. In: BRANCO, Marcello Simâo (org.). Assembléia estelar: histórias de ficção científica política. Săo Paulo: Devir, 2010, p. 79-86

CAUSO, Roberto de Sousa (org.). Os melhores contos brasileiros de ficçâo científica. Săo Paulo: Devir, 2007.

ENRIQUEZ, Eugène. Matar sem culpa: algumas reflexōes sobre os assassinatos coletivos. In: NOVAES, Adauto (org.). Mutaçōes: fontes passionais da violência. Săo Paulo: Ediçōes Sesc Sáo Paulo, 2015.

GIRARD, René. Violence and the sacred. New York: Continuum, 2005.

GIROLDO, Ramiro. André Carneiro entre os Quânticos da Incerteza. In: CARNEIRO, André. O Teorema das Letras. Sāo Paulo: Devir, 2016.

MARTIN, Elizabeth A. A dictionary of law. 5aed. New York: Oxford University Press, 2003.

MINOIS, Georges. História do futuro: dos profetas à prospectiva. Traduçâo de Mariana Echalar. São Paulo: Editora Unesp, 2016.

MONTEIRO, Jeronymo. Tangentes da realidade. Săo Paulo: Livraria Quatro Artes, 1969.

REIS, Carlos. Dicionário de estudos narrativos. Coimbra: Almedina, 2018.

RIDENTI, Marcelo. Em busca do povo brasileiro: artistas da revoluçâo, do CPC à era da

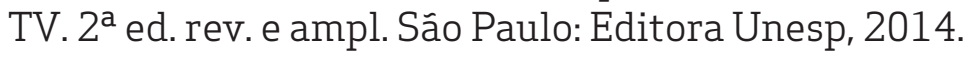

SANTOS, Naiara Sales Araújo. Brazilian Science Fiction and the Colonial Legacy. Sâo Luís: EDUFMA, 2014. 
SEVERO, José Antonio. A Invasâo. Porto Alegre: L\&PM Editores, 1979.

SILVA, Domingos Carvalho da. A véspera dos mortos. Sâo Paulo: Editora Coliseu, 1966.

SUVIN, Darko. Metamorphoses of Science Fiction: on the poetics and history of a literary genre. Berlin: Peter Lang, 2016. 